\title{
Death of Mr. Olof Stroh
}

The ICRC learned with great sadness of the death on 3 December 1989 of Mr. Olof Stroh, former Secretary General of the Swedish Red Cross. His passing deprives the Movement of one of its outstanding members of the last thirty years.

Mr. Stroh was born in Uppsala, Sweden, on 7 June 1918. After studying languages at Uppsala University, he took up a military career. He was successively appointed Military Secretary to the Parliamentary Defence Committee (1955-1958), Expert to the Government for the Reorganization of Civil Defence (1956) and Expert to the Committee for the Reorganization of the Top-Level Military Command (1958-1960).

He worked as a delegate for the World Health Organization in 1960 during the paralysis epidemic caused by adulterated cooking oil in the Meknes area of Morocco.

At the end of 1960 he was appointed Secretary General of the Swedish Red Cross, a post he occupied until he retired in 1978. In this capacity, he took part in many of the Movement's meetings worldwide and carried out important missions which gave his career a prominent international dimension.

In January 1967 he was appointed Chief Delegate of the League of Red Cross Societies in the Republic of Viet Nam for the international relief operation for civilians launched by the League at the request of the country's National Society. In October 1972, after a cease-fire took effect in Indochina, he was assigned to conduct a survey there. In December of the same year he was appointed head of the Indochina Operational Group (IOG) set up by the ICRC and the League to protect and assist those in need in the war-stricken areas of Indochina. He worked in this capacity until March 1974.

After retiring, Mr. Stroh continued to work at the international level. From 1981 to 1982, as Special Assistant to the Secretary General of the League in charge of operations, he played a leading role in the joint League/ICRC operation in Poland and from 1981 to 1984 was co-director (with J.-P. Hocké, then ICRC Director of Operations) of the "Poland Operation Group". He also acted as a League representative at the Assembly of the Henry Dunant Institute. 
Both an idealist and a realist, Mr. Stroh devoted his exceptional intellect to the advancement of the Movement's humanitarian ideals. In his quest for perfection, he not only took action but also gave it careful thought and regular reconsideration, aware as he was of the Movement's need to adapt to a constantly changing world. Always guided in his work by the fundamental principles of the Red Cross and Red Crescent, he was a man of high achievement, well aware of practical realities, who proved a skilful co-ordinator and whose every action demonstrated a deep concern for preserving the Movement's unity and respecting its components' specific mandates.

The ICRC members and staff who knew Mr. Stroh will long remember him as a man of great distinction, generosity and warmth totally devoted to serving humanity.

Mr. Stroh was laid to rest in Stockholm on 15 December 1989. The ICRC was represented at his funeral by Mr. Michel Convers, Director of its Operational Support Department, who paid him the following tribute: "The Red Cross owes much to Olof Stroh, both nationally and internationally. He has left us a message and an example. The best way for us to mark our respect for him is to follow in his footsteps". 